\title{
Detection of dengue virus in saliva and urine by real time RT-PCR
}

\author{
Telma R Poloni', Anibal S Oliveira', Helda L Alfonso', Larissa R Galvão', Alberto A Amarilla², Dimair F Poloni', \\ Luiz T Figueiredo ${ }^{2}$, Victor H Aquino ${ }^{1 *}$
}

\begin{abstract}
Early diagnosis of dengue virus (DENV) infection is important for patient management and control of dengue outbreaks. The objective of this study was to analyze the usefulness of urine and saliva samples for early diagnosis of DENV infection by real time RT-PCR. Two febrile patients, who have been attended at the General Hospital of the School of Medicine of Ribeirao Preto, Sao Paulo University were included in the study. Serum, urine and saliva samples collected from both patients were subjected to real time RT-PCR for DENV detection and quantification. Dengue RNA was detected in serum, urine and saliva samples of both patients. Patient 1 was infected with DENV-2 and patient 2 with DENV-3. Data presented in this study suggest that urine and saliva could be used as alternative samples for early diagnosis of dengue virus infection when blood samples are difficult to obtain, e.g., in newborns and patients with hemorrhagic syndromes.
\end{abstract}

\section{Finding}

Infection with any of the four dengue virus serotypes can lead to a broad clinical spectrum, ranging from subclinical infection or an influenza-like disease known as dengue fever (DF) to a severe, sometimes fatal, disease characterized by hemorrhage and plasma leakage that can lead to shock, known as dengue hemorrhagic fever/ dengue shock syndrome (DHF/DSS)[1,2]. Laboratory diagnosis of DENV infection is based on virus isolation, detection of virus antigen or RNA and detection of DENV specific antibodies in serum or plasma [3]. Realtime reverse transcription-polymerase chain reaction (RT-PCR) has been developed to detect DENV RNA in human samples [4-7]. This technique is an important tool for the rapid diagnosis of DENV infection allowing early initiation of patient management and specific preventive health measures. The objective of this study was to analyze the usefulness of urine and saliva samples for early diagnosis of DENV infection by real time RT-PCR. The Hospital Ethics Committee of the School of Medicine of Ribeirao Preto, Sao Paulo University has approved this study (Proc. 4921/2007).

\footnotetext{
* Correspondence: vhugo@fcfrp.usp.br

'Departamento de Análises Clínicas, Toxicológicas e Bromatológicas, Faculdade de Ciências Farmacêuticas, Universidade de São Paulo, Ribeirão Preto14040-903, Av. Do Café s/n, São Paulo, Brasil
}

Two febrile patients attended at the General Hospital of the School of Medicine of Ribeirao Preto, Sao Paulo University, were included in the study. Both patients were female, 30 (patient 1) and 13 (patient 2) years old, and presented symptoms suggestive of DF with high fever, frontal headache, arthralgia, myalgia and retroocular pain. The patients received supportive treatment including bedrest, antipyretics, analgesics and oral fluid replacement, and had a good outcome without any complication. Serum, urine and saliva samples were collected, two and nine days after the onset of symptoms, from both patients, and subjected to a quantitative real time RT-PCR for dengue as described earlier [7]. Dengue RNA was detected in all clinical samples collected two days after the onset of symptoms from both febrile patients (Table 1). Serum showed a viral load higher than urine and saliva samples. To identify the virus serotype, the entire E protein gene was amplified from the sera and subjected directly to DNA sequencing for phylogenetic analysis as previously mentioned [8]. This analysis showed that patient 1 was infected with dengue virus type 2 and patient 2 with dengue virus type 3 (Figure 1). The clinical samples were also subjected to a capture ELISA for dengue-specific IgM/IgG as previously mentioned [7]. Both patients presented seroconversion indicating a primary infection (Table 1 ). For virus isolation, $20 \mu \mathrm{l}$ of each clinical sample were added 


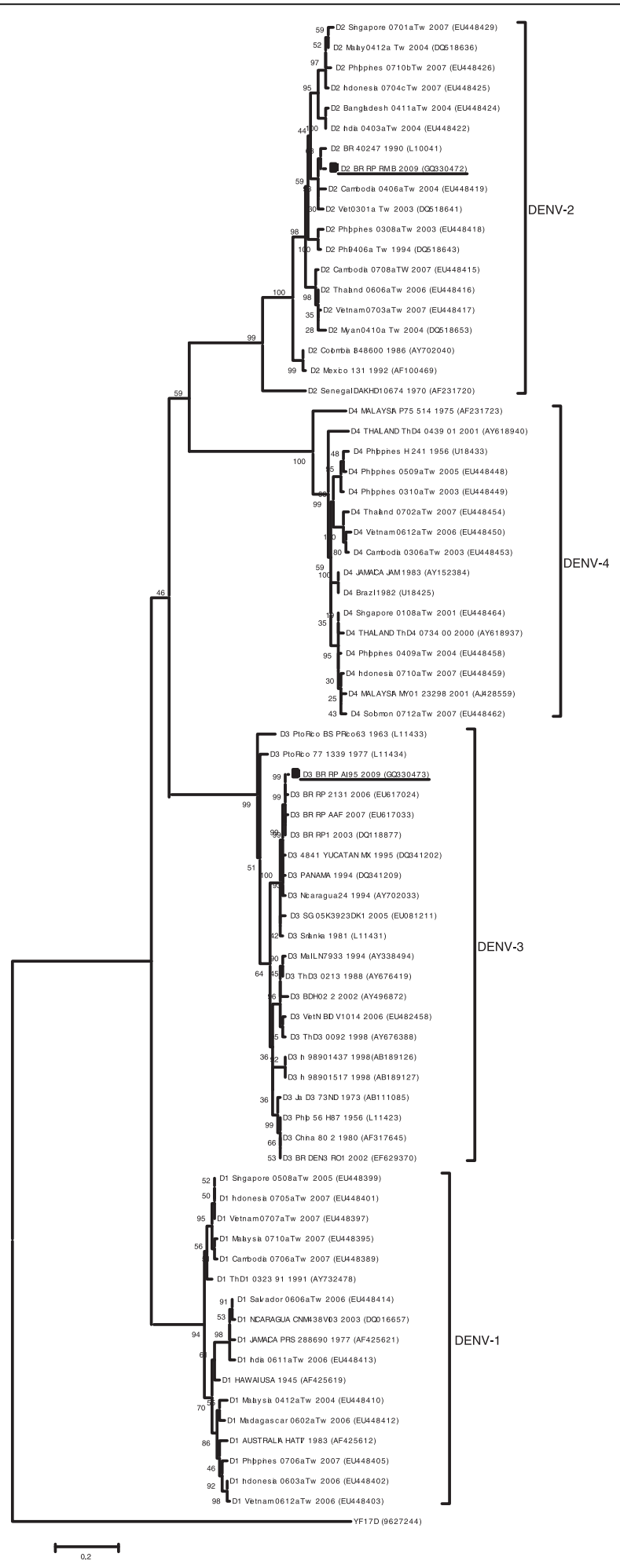

Figure 1 Phylogenetic tree based on the E gene sequences using Neighbor-joining ( $\mathrm{NJ}$ ) method showing the relationship of viruses isolated in this study with $\mathbf{7 2}$ global samples of DENV. Tamura and $\mathrm{Nei}(\mathrm{TrN}+\mathrm{I}+\mathrm{G})$ nucleotide substitution model was used with a proportion of invariable sites (I) of 0.2096 and gamma distribution $(\mathrm{G})$ of 0.6072 using the hierarchical likelihood ratio test (hLTR). The YF17D (9627244) was used as outgroup. Horizontal branch lengths are drawn to scale. Viruses isolated from patients 1 and 2 are underlined. GenBank accession numbers are indicated in parenthesis. 
Table 1 Dengue diagnostic tests performed in clinical samples from the two patients.

\begin{tabular}{|c|c|c|c|c|c|c|c|c|c|c|c|c|}
\hline & \multicolumn{6}{|c|}{2 days after onset of symptoms } & \multicolumn{6}{|c|}{9 days after onset of symptoms } \\
\hline & \multicolumn{3}{|l|}{ Patient 1} & \multicolumn{3}{|l|}{ Patient 2} & \multicolumn{3}{|c|}{ Patient 1} & \multicolumn{3}{|c|}{ Patient 2} \\
\hline & Serum & Saliva & Urine & Serum & Saliva & Urine & Serum & Saliva & Urine & Serum & Saliva & Urine \\
\hline Viral load (PFU/ml) & $7.9 \times 10 \mathrm{E} 2$ & $3 \times 10 \mathrm{E}-1$ & $4 \times 10 \mathrm{E}-1$ & $1.9 \times 10 \mathrm{E} 5$ & $1 \times 10 \mathrm{E}-1$ & $5 \times 10 \mathrm{E}-1$ & $\mathrm{~N}$ & $\mathrm{~N}$ & $\mathrm{~N}$ & $\mathrm{~N}$ & $\mathrm{~N}$ & $\mathrm{~N}$ \\
\hline $\lg ^{*}$ & ND & ND & ND & ND & ND & ND & 1.15 & 0.84 & 0.60 & 1.25 & 0.89 & 0.54 \\
\hline lgG\# & ND & ND & ND & ND & ND & ND & 0.78 & 0.84 & 0.65 & 0.82 & 0.83 & 0.56 \\
\hline Virus Isolation & DENV-2 & $\mathrm{N}$ & $\mathrm{N}$ & DENV-3 & $\mathrm{N}$ & $\mathrm{N}$ & $N$ & $N$ & $N$ & $\mathrm{~N}$ & $N$ & $\mathrm{~N}$ \\
\hline
\end{tabular}

$\mathrm{N}$ : negative. *IgM detection: cut off 0.63 ; \#lgG detection: cut off 0.68 . ND: not detectable.

to a $25 \mathrm{~cm}^{2}$ flask containing a monolayer of $\mathrm{C} 6 / 36$ cells and seven days after inoculation, the supernatant was subjected to the real time RT-PCR to confirm virus isolation. Dengue virus was isolated from the serum samples collected two days after the onset of symptoms from both patients (Table 1). In order to avoid any kind of contamination, all procedures of virus isolation, RNA purification, protein E gene amplification, PCR product analysis and DNA sequencing were performed in different rooms following good laboratory practice guidelines.

In addition to serum, we were able to detect dengue virus in both urine and saliva samples by real time RTPCR. In a previous case report study, dengue virus was detected in urine and saliva samples up to 14 days after the onset of fever, when no viremia was detected, suggesting that the virus could remain in urine and saliva for a longer period of time than in serum [9]. However, in our study, dengue virus was detected in serum, urine and saliva samples of both patients, two days after the onset of symptoms, but not after nine days. The lower viral load found in urine and saliva compared to serum suggests that dengue virus would be detected in these clinical samples for a shorter period of time.

Recently, the usefulness of saliva in dengue serologic diagnosis has been studied showing that specific IgM could be detected in patients with primary infection and IgM/IgG in patients with secondary infection [10]. We were able to detect IgM and IgG in the two patients with a primary infection.

Our results suggest that urine and saliva samples could be used for dengue diagnosis in cases where blood samples are difficult to obtain, such as in newborns or in patients with hemorrhagic syndromes. Urine and saliva samples are easy to collect without invasive procedures and urine samples can be collected in large volumes. However, further studies, with a higher number of patients, are needed to confirm these results.

\section{List of abbreviations}

(DENV): Dengue virus; (DF): Dengue fever; (DHF/DSS): Dengue hemorrhagic fever/dengue shock syndrome; (RT-PCR): Reverse transcription-polymerase chain reaction; (NJ): Neighbor-joining; (hLTR): Hierarchical likelihood ratio test.

\section{Acknowledgements}

This work was supported by a grant from Fundação de Amparo a Pesquisa do Estado de São Paulo (FAPESP) and by the Instituto Nacional de Ciência e Tecnologia (INCT) em Dengue: http://www.cnpq.br/programas/inct/ _apresentacao/inct_dengue.html).

\section{Author details}

${ }^{1}$ Departamento de Análises Clínicas, Toxicológicas e Bromatológicas, Faculdade de Ciências Farmacêuticas, Universidade de São Paulo, Ribeirão Preto14040-903, Av. Do Café s/n, São Paulo, Brasil. ${ }^{2}$ Centro de Pesquisa em Virologia, Faculdade de Medicina de Ribeirão Preto, Universidade de São Paulo, Ribeirão Preto 14049-900, Av. Bandeirantes 3900, São Paulo, Brasil. ${ }^{3}$ Hospital das Clínicas da Faculdade de Medicina de Ribeirão Preto, Universidade de São Paulo, Ribeirão Preto 14049-900, Av. Bandeirantes 3900, São Paulo, Brasil.

\section{Authors' contributions}

TP and AO carried out the real time RT-PCR.

$\mathrm{HA}$ and AA carried out the phylogenetic analysis.

LG carried out the serological work.

DP conducted the medical attention.

TP and LF co-wrote and edited the manuscript.

VA organized the overall project and helped edit the manuscript.

All authors read and approved the final manuscript.

\section{Competing interests}

The authors declare that they have no competing interests.

Received: 17 November 2009

Accepted: 27 January 2010 Published: 27 January 2010

\section{References}

1. Halstead S: Pathogenesis of dengue: challenges to molecular biology. Science 1988, 239:476-481.

2. Gubler D: Epidemic dengue/dengue hemorrhagic fever as a public health, social and economic problem in the 21st century. Trends Microbiol 2002, 10:100-103.

3. Halstead S: Dengue. Lancet 2007, 370:1644-1652.

4. Callahan J, Wu S, Dion-Schultz A, Mangold B, Peruski L, Watts D, Porter K, Murphy G, Suharyono W, King C, Hayes CG, Temenak JJ: Development and evaluation of serotype- and group-specific fluorogenic reverse transcriptase PCR (TaqMan) assays for dengue virus. J Clin Microbiol 2001, 39:4119-4124.

5. Drosten C, Göttig S, Schilling S, Asper M, Panning M, Schmitz H, Günther S: Rapid detection and quantification of RNA of Ebola and Marburg viruses, Lassa virus, Crimean-Congo hemorrhagic fever virus, Rift Valley fever virus, dengue virus, and yellow fever virus by real-time reverse transcription-PCR. J Clin Microbiol 2002, 40:2323-2330.

6. Johnson B, Russell B, Lanciotti R: Serotype-specific detection of dengue viruses in a fourplex real-time reverse transcriptase PCR assay. J Clin Microbiol 2005, 43:4977-4983. 
7. Dos Santos HWG, Poloni T, Souza KP, Muller VDM, Tremeschin F, Nali LC, Fantinatti LR, Amarilla AA, Castro HLA, Nunes MR, Casseb SM,

Vasconcelos PF, Badra SJ, Figueiredo LT, Aquino VH: A simple one-step real-time RT-PCR for diagnosis of dengue virus infection. Journal of Medical Virology 2008, 80:1426-1433.

8. Amarilla A, de Almeida F, Jorge D, Alfonso H, de Castro-Jorge L, Nogueira N, Figueiredo L, Aquino V: Genetic diversity of the E protein of dengue type 3 virus. Virol J 2009, 6:113.

9. Mizuno Y, Kotaki A, Harada F, Tajima S, Kurane I, Takasaki T: Confirmation of dengue virus infection by detection of dengue virus type 1 genome in urine and saliva but not in plasma. Trans R Soc Trop Med Hyg 2007, 101:738-739.

10. Vázquez $\mathrm{S}$, Cabezas S, Pérez A, Pupo M, Ruiz D, Calzada N, Bernardo L, Castro O, González D, Serrano T: Kinetics of antibodies in sera, saliva, and urine samples from adult patients with primary or secondary dengue 3 virus infections. Int J Infect Dis 2007, 11:256-262.

doi:10.1186/1743-422X-7-22

Cite this article as: Poloni et al: Detection of dengue virus in saliva and urine by real time RT-PCR. Virology Journal 2010 7:22.

\section{Submit your next manuscript to BioMed Central} and take full advantage of:

- Convenient online submission

- Thorough peer review

- No space constraints or color figure charges

- Immediate publication on acceptance

- Inclusion in PubMed, CAS, Scopus and Google Scholar

- Research which is freely available for redistribution

Submit your manuscript at www.biomedcentral.com/submit 